\title{
INSECT DAMAGE AND POWDERY MILDEW SEVERITY IN SOYBEAN CULTIVARS AND LINES
}

\author{
André Luiz Lourenção ${ }^{1 *}$; Nelson Raimundo Braga ${ }^{1}$; Manoel Albino Coelho de Miranda ${ }^{1}$; Paulo \\ César Reco ${ }^{1}$; Giuliana Etore do Valle ${ }^{2}$ José Carlos Vila Nova Alves Pereira ${ }^{1}$ \\ ${ }^{1}$ IAC - C.P. 28 - 13001-970 - Campinas, SP - Brasil. \\ ${ }^{2}$ USP/CENA - Programa de Pós-Graduação em Energia Nuclear na Agricultura, C.P. 96 - 13416-000 - Piracicaba, \\ $S P$ - Brasil. \\ *Corresponding author <andre@iac.sp.gov.br>
}

\begin{abstract}
The use of soybean cultivars resistant to insects and diseases reduces the application of pesticides, decreasing production costs and promoting a sustainable agriculture. The damage of stink bugs and defoliators and the severity of powdery mildew (Microsphaera diffusa) in soybean of three maturity groups were evaluated under field conditions, at Tarumã and Ribeirão Preto, State of São Paulo, Brazil. Three experiments, one for each group, were carried out in the 1999/2000 and 2000/2001 growing seasons. In 1999/2000, the disease occurred in Tarumã; in that year, infestation of chrysomelids (Cerotoma sp. and Colaspis sp.) was observed in Ribeirão Preto. Low infestations of stink bugs occurred in both years and locations, but in Tarumã, at the stage of plant maturation, the insect population exceeded the economic injury level. The severity of powdery mildew was evaluated using a scale varying from 1 (no symptom) to 5 (more than $50 \%$ of leaves with symptoms). Chrysomelid injuries were estimated by the percentage of leaf area removed, and stink bug damage was evaluated by the percentage of leaf retention (LRP) and yield. Within the early maturity group (110 days), IAC 94-2675 showed good yield levels, low LRP, and resistance to powdery mildew. In the genotypes of the 120-day maturity group, IAC 94-5, IAC 94-1172, IAC 94-1017, IAC 94-133, and IAC 94-745 presented good yield; the last two behaved as resistant to the disease. With regard to the genotypes of the 135-day maturity group, IAC 93-1564 and IAC 94-2939 showed good yield, low LRP, and resistance to powdery mildew.
\end{abstract}

Keywords: Glycine max, Microsphaera diffusa, host plant resistance, stink bugs, defoliators

\section{DANOS DE INSETOS E SEVERIDADE DE OÍDIO EM CULTIVARES E LINHAGENS DE SOJA}

RESUMO: A utilização de cultivares de soja resistentes a pragas e doenças reduz a aplicação de pesticidas, diminuindo custos de produção e favorecendo uma agricultura sustentável. Assim, avaliaram-se os danos causados por percevejos e coleópteros crisomelídeos e a severidade de oídio (Microsphaera diffusa) em cultivares e linhagens de soja de ciclos precoce, semiprecoce e médio, em experimentos de campo instalados em Tarumã e Ribeirão Preto (SP), em 1999/2000 e 2000/2001. Em 1999/2000, essa doença atingiu a área experimental de Tarumã; ainda nesse ano, houve infestação de coleópteros crisomelídeos (Cerotoma sp. e Colaspis sp.) em Ribeirão Preto. Percevejos ocorreram nas duas localidades em baixas infestações, ultrapassando o nível de dano econômico em Tarumã, nos dois anos, apenas na fase de maturação. A severidade da doença foi avaliada mediante escala de notas, variando de 1 a 5 . As injúrias de coleópteros foram avaliadas estimando-se a porcentagem de área foliar cortada (PAFC) e os danos de percevejos através da porcentagem de retenção foliar (PRF) e da produtividade. Baseando-se em todos os experimentos, infere-se que, entre o germoplasma de ciclo precoce, a linhagem IAC 94-2675 apresenta níveis de produtividade comparáveis aos de material comercial, baixos índices de PRF, além de resistência a oídio. No grupo semiprecoce, as linhagens IAC 94-5, IAC 94-1172, IAC 94-1017, IAC 94-133 e IAC 94-745 exibem boa produtividade, sendo as duas últimas resistentes a oídio. Entre os genótipos de ciclo médio, destacam-se as linhagens IAC 93-1564 e IAC 94-2939, resistentes a oídio, com baixos índices de PRF e boa produtividade.

Palavras-chave: Glycine max, Microsphaera diffusa, resistência de plantas a insetos, Pentatomidae, insetos desfolhadores

\section{INTRODUCTION}

Even though representing costs of about only $5 \%$ of the total input used in soybean crops (FNP Consultoria e Comércio, 2003), because of the extensive areas planted in Brazil, large amounts of insecticides are used to reduce damage caused by pests. The most important insects whose populations can more frequently reach the economic injury level consist of those with defoliating (caterpillars and coleopterans) and sucking habits (pentatomid 
bugs) (Hoffmann-Campo et al., 2000). With regard to diseases, soybean powdery mildew (Microsphaera diffusa Cke. Pk.) used to be considered a secondary disease (Yorinori, 1982), until a severe incidence was observed in several cultivars during the 1996/97 cropping season, reaching all Brazilian producing regions, from the cerrado down to Rio Grande do Sul (Embrapa, 2001). From that season forward, the incidence of mildew has been frequent in soybean crops in the State of São Paulo, occurring nearly every year in the main producing regions.

Plant resistance to insects is an important component of integrated pest management programs (Adkisson \& Dyck, 1980); in a like manner, this is the case with diseases as well. Therefore, the use of soybean cultivars resistant to its main pests and diseases can reduce the need for pesticide applications, contributing to decrease yield costs, in addition to being beneficial to the environment.

In 1976, Instituto Agronômico de Campinas (IAC) initiated a new research area in its soybean breeding program, in order to obtain cultivars resistant to defoliating and sucking insects, which continues being developed today, with good results (Miranda \& Lourenção, 2002). Within this area, cultivars IAC 100 (Rossetto et al., 1989), IAC 17, IAC 19 (Valle \& Lourenção, 2002), IAC 23, and IAC 24 (Miranda et al., 2003a; 2003b) were obtained and released to growers, in addition to line IAC 78-2318, which has multiple resistance (Lourenção \& Miranda, 1987), and could be used in breeding programs focused at obtaining germplasm that is resistant to insects. Even though evaluations are carried out to identify lessdamaged plants, the occurrence of low infestations of insects in the experimental areas of IAC in some seasons in Campinas, where the program is conducted, could lead to the selection of lines that do not possess adequate resistance levels. Thus, at the end of each selection cycle, the most important lines must be evaluated in other regions that are preferably representative of soybean cropping, for a more detailed evaluation of resistance to insects and diseases, and also productivity, which is the objective of this work.

\section{MATERIAL AND METHODS}

Three experiments were installed, one for each genotype maturation group (110-day, 120-day and 135day), in the cities of Ribeirão Preto and Tarumã, in the State of São Paulo, during the 1999/2000 and 2000/2001 growing seasons. The same experiment area was used at each locality, in both years, and the experiments were arranged in an adjacent manner. Selection of the areas for experimentation was based on their history, particularly in Tarumã, where bug and defoliator infestations have been intense in the region's soybean crops (Lourenção et al., 2002). 120-day maturity group - Seven lines of the IAC-94 series and three cultivars were evaluated: 'IAC-17', a resistance standard, 'IAC-22', a productivity standard, and 'Coodetec-201', a cultivar planted in a wide area of the State of São Paulo (Table 1). In most lines and in 'IAC17', the presence of D 72-9601-1 in the germplasm's genealogy must be pointed out; this line was selected in the USA for resistance to Pseudoplusia includens (Walker), and showed little defoliation caused by Anticarsia gemmatalis Hubner under Brazilian conditions (Rezende et al., 1980). Identical experiments for the genotypes of this cycle were installed in Tarumã, sown on 12/15/1999 and on 11/20/2000, and in Ribeirão Preto, sown on 11/ $26 / 1999$ and on 11/24/2000. The experimental design was arranged as random blocks, with ten treatments and six replicates. Each plot consisted of four 5m-long rows, spaced at $0.5 \mathrm{~m}$ between each other.

Fertilization was performed in the planting furrow, according to recommendations for this crop (Raij et al., 1997), based on soil fertility analyses. The 0-20-20 rate was used in Ribeirão Preto, at $350 \mathrm{~kg} \mathrm{ha}^{-1}$ in both years; in Tarumã, the same rate was used (265 kg ha $)$ in the first year, and the 4-20-20 rate $\left(300 \mathrm{~kg} \mathrm{ha}^{-1}\right)$ was used in the second. No pesticide applications were performed during the entire plant cycle. Beginning at the onset of flowering, bug population surveys were carried out by the beat sheet method (Hoffmann-Campo et al., 2000); surveys extended up until the end of the pod maturation period.

120-day maturity group - In this experiment, eight lines (five in the IAC-94 and three in the IAC-97 group) and cultivars IAC-18, IAC-100 (resistant control), EMBRAPA-48, and BR-37 were used, the latter two representing extensive planting areas in São Paulo (Table 1). All lines tested presented D 72-9601-1 in their genealogies (Table 1). Similarly as for the 110-day maturity group germplasm, an experiment was installed in Ribeirão Preto and Tarumã, on the same seeding dates. The experimental design was organized as random blocks, with twelve treatments replicated six times. Plot size, row spacing, bug surveys, and other experimental procedures were similar to those used in the 110-day maturity group experiment.

135-day maturity group - Using the same ways and conditions employed for 110-, and 120-day maturity groups, experiments were installed in Ribeirão Preto and Tarumã, on the same dates, consisting of cultivars 'IAC PL-1', which is a standard for insect susceptibility, and 'Conquista', which is planted in a large area in São Paulo, two IAC-93 lines, and four IAC-94 lines. Line IAC 782318, which bears multiple resistance to insects (Lourenção \& Miranda, 1987) was used as a resistance standard (Table 1). The genealogy within this cycle is di- 
Table 1 - Genealogy of 110-, 120- and 135-day maturity group soybean cultivars and lines, evaluated in the field for resistance to insects and diseases, in Tarumã and Ribeirão Preto/SP, Brazil, during the 1999/2000 and 2000/2001 cropping seasons.

\begin{tabular}{|c|c|c|}
\hline Maturity group & Cultivar/line & Genealogy \\
\hline & 'IAC-17' & D 72-9601-1' $\times$ IAC-8 \\
\hline & 'IAC-22' & FT-2 (late) x IAC-12 \\
\hline & 'Coodetec-201' & Ocepar-4 (Iguaçu) (5) x Tracy-M \\
\hline & IAC $94-11$ & IAS-5 x (D 72-9601-1 x IAC-8) \\
\hline \multirow[t]{11}{*}{ 110-day } & IAC $94-27$ & IAS-5 $\times($ D 72-9601-1 $\times$ IAC-8) \\
\hline & IAC $94-105$ & IAS-5 x (D 72-9601-1 x IAC-8) \\
\hline & IAC $94-282$ & (D 72-9601-1 $\times$ IAC-8) $\times$ IAC 83-67 \\
\hline & IAC $94-790$ & (IAC 77-3086 x Paraná) x (D 72-9601-1 x IAC-8) \\
\hline & IAC $94-2675$ & IAC-13 x IAC $82-3411$ \\
\hline & IAC $93-3269$ & [D 72-9601-1 x F1 (Davis x PI 227687)] x IAC 83-46 \\
\hline & 'IAC-18' & D 72-9601-1 x IAC-8 \\
\hline & 'IAC-100' & IAC-12 x IAC $78-2318$ \\
\hline & 'Embrapa 48' & (Davis $x$ Paraná) $\times($ IAS-4 x BR-5) \\
\hline & 'BR-37' & União (2) x Lo 76-1763 \\
\hline & IAC $94-5$ & IAC-5 $\times(D$ 72-9601-1 $\times$ IAC-8) \\
\hline \multirow[t]{11}{*}{ 120-day } & IAC $94-133$ & D 72-9601-1 x IAC-8) x (IAC 77-3086 x Paraná)S \\
\hline & IAC $94-745$ & IAC $83-1003 \times(D$ 72-9601-1 x IAC-8) \\
\hline & IAC $94-1017$ & IAC-15 x (D 72-9601-1 x IAC-8) \\
\hline & IAC $94-1172$ & IAC-15 x (D 72-9601-1 x IAC-8) \\
\hline & IAC $97-2288$ & IAC-12 x (IAC-8 x D 72-9601-1) \\
\hline & IAC $97-2289$ & IAC-12 x (IAC-8 x D 72-9601-1) \\
\hline & IAC $97-2292$ & $($ IAC-13 $\times$ IAC $82-3411) \times$ IAC-17 \\
\hline & 'IAC PL-1' & unknown; selection made on germplasm from Japan \\
\hline & 'Conquista' & Lo 76-4484 x Numbaíra \\
\hline & IAC $78-2318$ & D 72-9601-1 x (Hill x PI 274454) \\
\hline & IAC $93-1489$ & (IAC 77-3086 x Paraná) x FT-10 \\
\hline \multirow[t]{5}{*}{ 135-day } & IAC $93-1564$ & FT-10 x IAC $79-440$ \\
\hline & IAC $94-2764$ & $($ IAC-13 $\times$ IAC $82-3413)+\left(\right.$ IAC-14 $\times$ IAC $\left.82-23^{2}\right)+($ IAC $82-23 \times$ IAC-14 $)$ \\
\hline & IAC $94-2853$ & $($ IAC-13 $\times$ IAC $82-3413)+\left(\right.$ IAC-14 $\times$ IAC $\left.82-23^{2}\right)+($ IAC $82-23 \times$ IAC-14 $)$ \\
\hline & IAC $94-2864$ & $($ IAC-13 x IAC $82-3413)+\left(\right.$ IAC-14 $\times$ IAC $\left.82-23^{2}\right)+($ IAC $82-23 \times$ IAC-14 $)$ \\
\hline & IAC $94-2939$ & $($ IAC-13 $\times$ IAC $82-3413)+\left(\right.$ IAC- $14 \times$ IAC $\left.82-23^{2}\right)+($ IAC $82-23 \times$ IAC- 14$)$ \\
\hline
\end{tabular}

versified, and only three lines in the IAC-94 group are derived from the same group of crosses involving line IAC 82-23, which, in turn, is a descendant from D 729601-1 (Table 1). The experimental design was arranged as random blocks, with nine treatments and six replicates.

Evaluation of damage by insects and of powdery mildew incidence - Whenever infestation reached levels that allowed germplasm discrimination, the leaf injuries caused by chrysomelid beetles were visually evaluated through the estimation of a defoliation percentage (PLAR - percentage leaf area removed), considering the entire plot. Damages caused by stink bugs were evalu- ated using two criteria: LRP (leaf retention percentage), for which an estimate of the percentage of plants showing retention of leaves after complete pod maturation, and/or showing green stalks was attributed to each plot, and yield from the two central rows, excluding the ini-

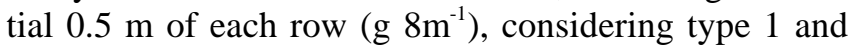
type 2 grain only, according to Jensen \& Newsom (1972). Severity of the disease in each plot was visually estimated for mildew by means of a rating scale ranging from 1 to 5 , where: $1=$ absence of leaf symptoms; $2=$ up to $10 \%$ of leaves showing symptoms; $3=$ from 11 to $25 \% ; 4=$ from 26 to $50 \%$, and $5=$ over $50 \%$. 
Statistical analysis - The PLAR and LRP values were transformed to arc sine $\sqrt{x / 100}$, while productivity and mildew rating values were analyzed without transformation. A non-parametric analysis was performed for mildew using Kruskal-Wallis and a non-parametric multiple comparisons test. Per-year and joint analyses of variance were run for PLAR, LRP, and productivity, and the means were compared by Tukey test $(P<0.05)$.

\section{RESULTS AND DISCUSSION}

110-day maturity group - With regard to defoliating insects, an infestation of chrysomelid beetles occurred in the 1999/2000 cropping season in Ribeirão Preto, with predominance of Colaspis sp. over Cerotoma sp., when the plants were at the $\mathrm{R}_{4} / \mathrm{R}_{5}$ developmental stages, according to Fehr \& Caviness (1977). The genotype showing the highest defoliation index was 'IAC 22' (Table 2), which confirms observations by Lourenção et al. (2002), who verified the greatest PLAR means due to chrysomelids in that cultivar, during two consecutive years in Tarumã, as compared to other cultivars and lines. The lowest defoliation was observed for line IAC 94-282, whose mean did not differ from 'IAC 17' and IAC 94105.

Considering the effect of stink bugs, the yeartreatment interaction was significant for both criteria used, LRP and productivity, at the Ribeirão Preto location, but not at Tarumã, where only productivity was evaluated. In both the first and second years at Ribeirão Preto, stink bug populations oscillated below the economic injury level (Figure 1) of four sampled bugs (beat sheet method) starting at the $\mathrm{R}_{3}$ stage (formation of pods) in grain crops, and two stink bugs in seed production crops (HoffmannCampo et al., 2000). Under these low infestation conditions, LRP ranged from 5.0 ('IAC-17') to $61.7 \%$ (IAC 9411) in $1999 / 2000$ and from 1.7 (IAC 94-11) to $68.3 \%$ ('Coodetec-201') in 2000/2001 (Table 2). The extreme and reversed leaf retention values verified for line IAC 94-11 and cultivar 'Coodetec-201', under low stink bug pressure, reinforce the hypothesis that other factors, probably related to climate, would influence the expression of this important physiological disorder of the crop. Regardless of the cause, 'IAC-17' is a cultivar in which leaf retention practically does not occur, thus confirming previous results obtained in two cropping seasons (1997/98 and 1998/99), at these two locations (Lourenção et al., 2002). The best productivity at Tarumã was obtained by line IAC 94-2675, whose mean was different from all other treatments, except from IAC 94-27 (Table 3). In Ribeirão Preto, these two lines showed steady productivity means, not differing from the best treatments (Table 2 ); at the same location, cultivars 'IAC 22' and 'Coodetec-201' showed the lowest means in absolute values, which is a sign of good potential for all lines evaluated when it comes to productivity.

Table 2 - Means for percentage leaf area removed (PLAR) by chrysomelid beetles, leaf retention percentage (LRP), and

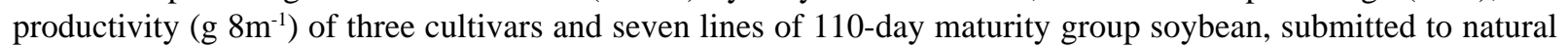
infestation by insects in the field. Ribeirão Preto, SP, Brazil, 1999/2000 and 2000/2001 [n =6].

\begin{tabular}{|c|c|c|c|c|c|c|c|}
\hline \multirow{2}{*}{ Cultivar/line } & \multirow{2}{*}{$\begin{array}{c}\text { PLAR }^{1} \\
1999 / 2000\end{array}$} & \multicolumn{3}{|c|}{$\mathrm{LRP}^{1}$} & \multicolumn{3}{|c|}{ Productivity ${ }^{1}$} \\
\hline & & $1999 / 2000$ & $2000 / 2001$ & Mean & $1999 / 2000$ & $2000 / 2001$ & Mean \\
\hline & -- & $\%$ & & & -- & g $8 \mathrm{~m}^{-1}$ & $-\cdots$ \\
\hline 'IAC-17' & $9.2 \pm 0.83 \mathrm{~cd}$ & $5.0 \pm 3.16 \mathrm{~d}$ & $7.5 \pm 3.10 \mathrm{c}$ & $6.2 \pm 0.57$ & $1,018 \pm 35.35 \mathrm{abc}$ & $1,183 \pm 90.51 \mathrm{a}$ & $1,100 \pm 28.09$ \\
\hline IAC 94-282 & $5.0 \pm 0.00 \mathrm{~d}$ & $23.3 \pm 5.11 \mathrm{bcd}$ & $4.2 \pm 2.39 \mathrm{c}$ & $13.7 \pm 1.73$ & $953 \pm 33.26 \mathrm{bc}$ & $1,238 \pm 89.56 \mathrm{a}$ & $1,095 \pm 36.29$ \\
\hline IAC 94-790 & $17.5 \pm 1.12 \mathrm{ab}$ & $47.5 \pm 8.14 \mathrm{ab}$ & $19.2 \pm 4.36 \mathrm{bc}$ & $33.3 \pm 3.33$ & $1,167 \pm 62.73 \mathrm{a}$ & $991 \pm 51.24 \mathrm{ab}$ & $1,079 \pm 13.46$ \\
\hline IAC 93-3269 & $13.3 \pm 2.47 \mathrm{abc}$ & $21.7 \pm 6.15 \mathrm{bcd}$ & $6.7 \pm 3.33 \mathrm{c}$ & $14.2 \pm 1.10$ & $989 \pm 49.01 \mathrm{abc}$ & $1,166 \pm 78.05 \mathrm{a}$ & $1,077 \pm 20.23$ \\
\hline IAC 94-27 & $15.8 \pm 2.01 \mathrm{abc}$ & $35.0 \pm 8.06 \mathrm{abc}$ & $46.7 \pm 16.87 \mathrm{ab}$ & $40.8 \pm 2.30$ & $1,137 \pm 54.57 \mathrm{ab}$ & $987 \pm 88.40 \mathrm{ab}$ & $1,062 \pm 20.33$ \\
\hline IAC 94-2675 & $15.8 \pm 1.54 \mathrm{abc}$ & $20.0 \pm 5.16 \mathrm{~cd}$ & $8.3 \pm 2.79 \mathrm{c}$ & $14.1 \pm 0.77$ & $1,117 \pm 38.40 \mathrm{ab}$ & $992 \pm 49.50 \mathrm{ab}$ & $1,054 \pm 13.23$ \\
\hline IAC 94-105 & $12.5 \pm 3.10 \mathrm{bcd}$ & $45.0 \pm 6.19 \mathrm{abc}$ & $10.8 \pm 3.00 \mathrm{c}$ & $27.9 \pm 4.09$ & $972 \pm 28.42 \mathrm{abc}$ & $1,122 \pm 74.36 \mathrm{a}$ & $1,047 \pm 18.51$ \\
\hline IAC 94-11 & $12.5 \pm 2.50 \mathrm{bc}$ & $61.7 \pm 6.67 \mathrm{a}$ & $1.7 \pm 1.67 \mathrm{c}$ & $31.7 \pm 6.62$ & $843 \pm 56.45 c$ & $1,138 \pm 43.64 \mathrm{a}$ & $990 \pm 37.85$ \\
\hline 'IAC-22' & $21.7 \pm 1.05 \mathrm{a}$ & $35.0 \pm 7.19 \mathrm{abc}$ & $25.0 \pm 6.58 \mathrm{bc}$ & $30.0 \pm 1.21$ & $999 \pm 23.54 \mathrm{abc}$ & $762 \pm 48.67 \mathrm{bc}$ & $880 \pm 22.95$ \\
\hline 'Coodetec-201' & $17.5 \pm 1.12 \mathrm{ab}$ & $8.3 \pm 2.79 \mathrm{~d}$ & $68.3 \pm 12.22 \mathrm{a}$ & $38.3 \pm 6.82$ & $1,091 \pm 42.67 \mathrm{ab}$ & $620 \pm 85.62 c$ & $855 \pm 54.23$ \\
\hline Mean & 14.1 & $30.2 \mathrm{~A}$ & $19.8 \mathrm{~B}$ & 25.0 & $1,028.6 \mathrm{~A}$ & $1,019.9 \mathrm{~A}$ & $1,023.9$ \\
\hline $\mathrm{s}(\mathrm{m})$ & 3.67 & 9.99 & 14.38 & 5.82 & 103.87 & 178.86 & 72.60 \\
\hline C.V. $(\%)$ & 17.05 & 32.0 & 62.2 & 20.3 & 10.1 & 17.6 & 7.1 \\
\hline
\end{tabular}

${ }^{1}$ Means followed by the same lower case letter in the column, and upper case letter in the row, do not differ by Tukey test $(P \leq 0.05)$. 
A generalized mildew infection occurred in the experiment area in Tarumã during the 1999/2000 cropping season, when plants were at full bloom. Among the cultivars, 'IAC-17' exhibited a behavior of resistance against this fungus, and no symptoms were
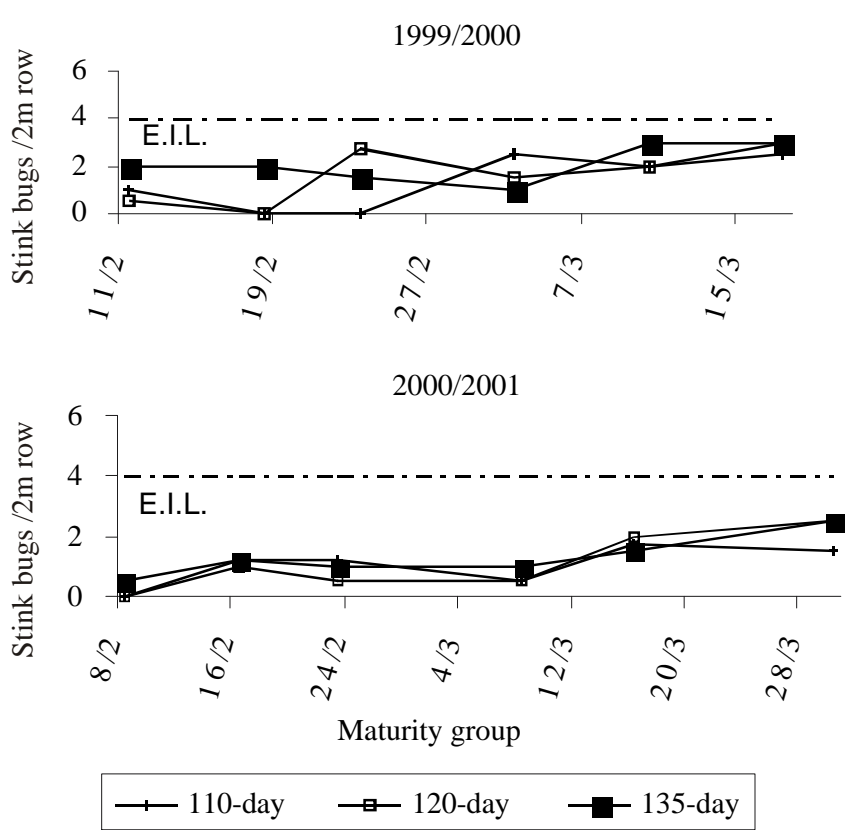

Figure 1 - Population fluctuation of stink bugs in soybean experiments at Ribeirão Preto, SP, Brazil, during the 1999/2000 and 2000/2001 cropping seasons.

E.I.L. = economic injury level observed on the plants' leaves (Table 3). 'IAC 22' plants also showed a low mean rating value (1.2), not differing from 'IAC 17'. These two cultivars had already been reported as resistant to mildew (Embrapa, 2002). In turn, 'Coodetec-201' was susceptible, with a mean rating value higher than all other genotypes. With regard to the IAC lines, the absence of symptoms must be pointed out in IAC 94-2675, IAC 94-27, and IAC 94-105.

120-day maturity group - A chrysomelid-beetle infestation in plants at the $\mathrm{R}_{4}$ stage during the 1999/2000 season in Ribeirão Preto caused mean defoliations between 7.5 (IAC 94-1017) and 20.8\% (IAC 97-2288) (Table 4). Besides IAC 94-1017, the lowest means were achieved by IAC $94-1172(8.3 \%)$ and by 'IAC-100' (8.3\%), which is a cultivar developed by IAC's soybean breeding program as resistant to stink bugs and defoliating insects (Rossetto, 1989); these were different from lines IAC 972288 and IAC 97-2292 and from cultivars Embrapa-48 and BR-37, which were the treatments with the highest PLAR indices.

In the stink bug damage evaluation, a year-treatment interaction was observed for productivity in both locations, and for LRP in Ribeirão Preto. In the latter, a marked effect of year can be observed under the LRP criterion, whose means were extremely high in 1999/2000 (Table 4). In that growing season, 'IAC-100' and 'Embrapa-48' showed means of 11.7 and $12.5 \%$, respectively. In the following season, leaf retention reached low levels in almost all treatments; only line IAC 97-2289 pre-

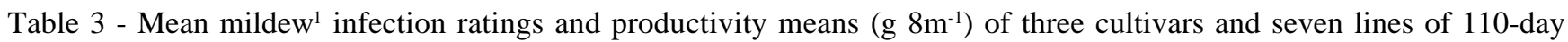
maturity group soybean, submitted to natural infestation by insects and diseases in the field. Tarumã, SP, Brazil, $1999 / 2000$ and 2000/2001 [n=6].

\begin{tabular}{|c|c|c|c|c|}
\hline \multirow{2}{*}{ Cultivar/line } & \multirow{2}{*}{$\begin{array}{l}\text { Mildew }^{2} \\
1999 / 2000 \\
\end{array}$} & \multicolumn{3}{|c|}{ Productivity $\left({\left.\mathrm{g} 8 \mathrm{~m}^{-1}\right)^{3}}^{3}\right.$} \\
\hline & & $1999 / 2000$ & $2000 / 2001$ & Mean \\
\hline IAC $94-2675$ & $1.0 \pm 0.00 \mathrm{~b}$ & $1,145 \pm 76.33$ & $1,110 \pm 46.77$ & $1,127 \pm 7.73 a$ \\
\hline IAC 94-27 & $1.0 \pm 0.00 \mathrm{~b}$ & $995 \pm 152.24$ & $1,166 \pm 46.96$ & $1,080 \pm 25.38 \mathrm{ab}$ \\
\hline IAC 94-105 & $1.0 \pm 0.00 \mathrm{~b}$ & $931 \pm 188.97$ & $1,142 \pm 79.17$ & $1,036 \pm 33.14 b c$ \\
\hline IAC 94-11 & $1.2 \pm 0.17 \mathrm{ab}$ & $992 \pm 66.42$ & $1,014 \pm 50.78$ & $1,003 \pm 11.01 \mathrm{bc}$ \\
\hline 'IAC-22' & $1.2 \pm 0.17 \mathrm{ab}$ & $992 \pm 148.80$ & $1,082 \pm 60.36$ & $1,002 \pm 28.69 b c$ \\
\hline IAC 93-3269 & $1.3 \pm 0.21 \mathrm{ab}$ & $827 \pm 81.21$ & $1,151 \pm 90.52$ & $989 \pm 45.17 b c$ \\
\hline 'IAC-17' & $1.0 \pm 0.00 \mathrm{~b}$ & $803 \pm 106.16$ & $1,098 \pm 81.72$ & $950 \pm 30.17 b c$ \\
\hline IAC 94-790 & $2.0 \pm 0.00 \mathrm{ab}$ & $791 \pm 74.32$ & $1,084 \pm 30.81$ & $937 \pm 39.75 \mathrm{c}$ \\
\hline 'Coodetec-201' & $2.8 \pm 0.17 \mathrm{a}$ & $721 \pm 111.47$ & $1,035 \pm 50.93$ & $878 \pm 30.89 c$ \\
\hline IAC 94-282 & $1.3 \pm 0.21 \mathrm{ab}$ & $718 \pm 148.21$ & $1,026 \pm 53.55$ & $872 \pm 38.16 \mathrm{c}$ \\
\hline Mean & 1.4 & $891.5 \mathrm{~B}$ & $1,090.8 \mathrm{~A}$ & 987.4 \\
\hline $\mathrm{s}(\mathrm{m})$ & 0.16 & 308.48 & 154.22 & 50.00 \\
\hline C.V. $(\%)$ & 1.3 & 24.9 & 14.1 & 5.1 \\
\hline
\end{tabular}

${ }^{1}$ Rating scale ranging from 1 to 5 , where $1=$ absence of symptoms in the leaves ... $5=$ more than $50 \%$ of leaves with mildew.

${ }^{2}$ Means followed by the same letter in the column do not differ among themselves by the Kruskal-Wallis and multiple comparisons nonparametric tests $(P<0.05)$

${ }^{3}$ Means followed by the same lower case letter in the column, and upper case letter in the row, do not differ by Tukey test $(P \leq 0.05)$. 
sented a mean near $80 \%$, indicating that it is a susceptible material regarding this physiological disorder. The stink bug populations did not reach the economic injury level during the entire plant cycle (Figure 2); therefore, other factors, probably related to climate, would play a role in the manifestation of leaf retention.

In the first year, at Tarumã, the most productive

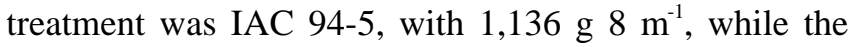
poorest performances were attained by 'IAC-100' and IAC 97-2289 (Table 5). In the following year, IAC 94-5 was again among the most productive, differing from IAC 972288, IAC 97-2292, and IAC 97-2289. In Ribeirão Preto, there was no significant difference between treatments in the first year (Table 4). In the following year, IAC 94-745 was the most productive, differing from lines IAC 97-2288 and IAC 97-2289, and from cultivars Embrapa-48, BR37 , and IAC-100, which showed the smallest means. Considering both cropping seasons and both localities, it can be seen that cultivar IAC-18 and lines IAC 94-5, IAC 94745 , and IAC 94-1172 showed mean productivity levels above $1,000 \mathrm{~g}^{-1}$; in addition, genotypes such as IAC 97-2289, which showed high leaf retention indices, and IAC 97-2288 and IAC 97-2292, which were the materials most defoliated by chrysomelid beetles, produced yields below that level. Even though they are resistant to
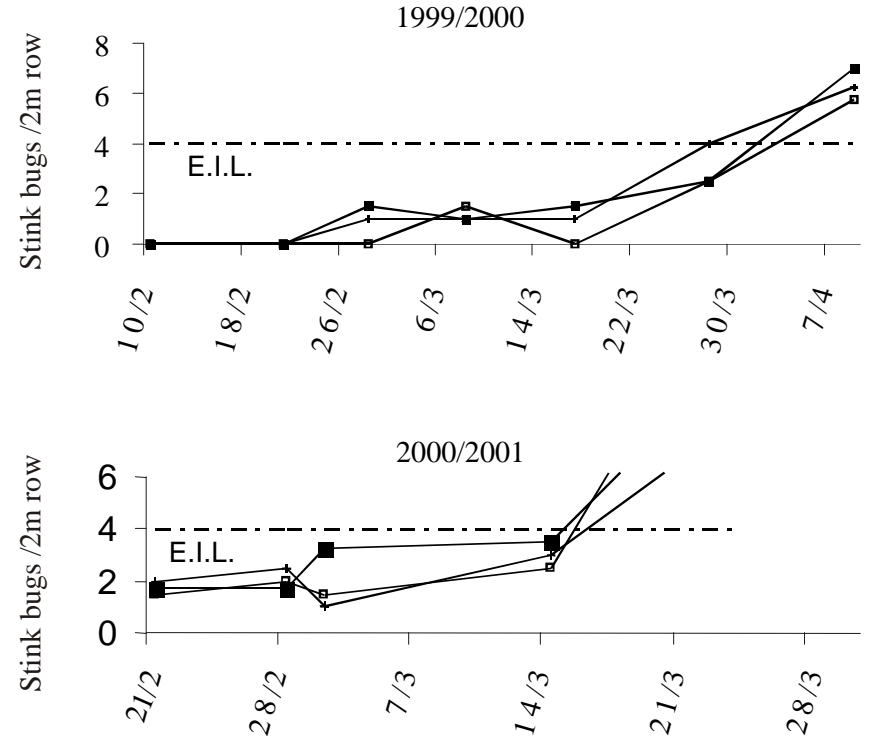

Maturity group

† 110-day $\rightarrow$ 120-day $\rightarrow$ 135-day

Figure 2 - Population fluctuation of stink bugs in soybean experiments at Tarumã, SP, Brazil, during the 1999/ 2000 and 2000/2001 cropping seasons.

E.I.L. $=$ economic injury level

Table 4 - Means for percentage leaf area removed (PLAR) by chrysomelid beetles, leaf retention percentage (LRP), and

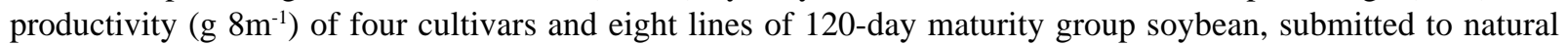
infestation by insects in the field. Ribeirão Preto, SP, Brazil, 1999/2000 and 2000/2001 [n = 6].

\begin{tabular}{|c|c|c|c|c|c|c|c|}
\hline \multirow{2}{*}{ Cultivar/line } & \multirow{2}{*}{$\frac{\text { PLAR }^{1}}{1999 / 2000}$} & \multicolumn{3}{|c|}{$\mathrm{LRP}^{1}$} & \multicolumn{3}{|c|}{ Productivity $^{1}$} \\
\hline & & $1999 / 2000$ & $2000 / 2001$ & Mean & $1999 / 2000$ & $2000 / 2001$ & Mean \\
\hline & 正 & $-\%-$ & - & -2 & $-\cdots$ & $-\operatorname{g~} 8 \mathrm{~m}^{-1} \cdots$ & - \\
\hline IAC $94-133$ & $11.7 \pm 2.11 \mathrm{bcd}$ & $61.7 \pm 13.02 \mathrm{bc}$ & $15.8 \pm 2.71 \mathrm{~b}$ & $38.7 \pm 4.12$ & $1,148 \pm 81.99 \mathrm{a}$ & $1,111 \pm 33.38 \mathrm{ab}$ & $1,129 \pm 12.01$ \\
\hline 'IAC 18' & $10.8 \pm 0.83 \mathrm{~cd}$ & $52.5 \pm 11.24 \mathrm{bcd}$ & $5.8 \pm 1.54 \mathrm{bc}$ & $29.1 \pm 3.96$ & $1,168 \pm 109.33 \mathrm{a}$ & $1,076 \pm 22.96 \mathrm{abc}$ & $1,122 \pm 21.57$ \\
\hline IAC $94-745$ & $9.2 \pm 0.83 \mathrm{~cd}$ & $72.5 \pm 13.65 \mathrm{ab}$ & $2.5 \pm 1.12 \mathrm{~cd}$ & $37.5 \pm 6.40$ & $1,065 \pm 57.07 \mathrm{a}$ & $1,172 \pm 49.49 \mathrm{a}$ & $1,118 \pm 15.52$ \\
\hline IAC $94-5$ & $10.0 \pm 1.29 \mathrm{~cd}$ & $56.7 \pm 9.89 \mathrm{bc}$ & $2.5 \pm 1.12 \mathrm{~cd}$ & $29.6 \pm 4.99$ & $1,027 \pm 52.77 \mathrm{a}$ & $1,089 \pm 57.67 \mathrm{abc}$ & $1,058 \pm 4.73$ \\
\hline IAC $94-1172$ & $8.3 \pm 1.05 \mathrm{~d}$ & $39.2 \pm 11.14 \mathrm{bcd}$ & $3.3 \pm 1.67 \mathrm{~cd}$ & $21.2 \pm 3.25$ & $980 \pm 53.83 \mathrm{a}$ & $1,045 \pm 22.25 \mathrm{abcd}$ & $1,012 \pm 7.82$ \\
\hline IAC 94-1017 & $7.5 \pm 1.12 \mathrm{~d}$ & $42.5 \pm 13.77 \mathrm{bcd}$ & $0.8 \pm 0.83 \mathrm{~d}$ & $21.6 \pm 3.28$ & $977 \pm 42.72 \mathrm{a}$ & $1,020 \pm 56.87 \mathrm{abcd}$ & $998 \pm 9.58$ \\
\hline 'Embrapa 48' & $15.0 \pm 1.83 \mathrm{abc}$ & $12.5 \pm 5.59 \mathrm{~d}$ & $0.8 \pm 0.83 \mathrm{~d}$ & $6.6 \pm 1.49$ & $1,159 \pm 33.80 \mathrm{a}$ & $833 \pm 90.54 \mathrm{~cd}$ & $996 \pm 31.93$ \\
\hline IAC $97-2288$ & $20.8 \pm 0.83 \mathrm{a}$ & $68.3 \pm 12.69 \mathrm{abc}$ & $15.0 \pm 3.57 \mathrm{~b}$ & $41.6 \pm 5.00$ & $1,025 \pm 34.11 \mathrm{a}$ & $899 \pm 61.34 \mathrm{bcd}$ & $962 \pm 9.51$ \\
\hline 'IAC 100' & $8.3 \pm 1.05 \mathrm{~d}$ & $11.7 \pm 7.71 \mathrm{~d}$ & $0.0 \pm 0.00 \mathrm{~d}$ & $5.8 \pm 1.88$ & $993 \pm 40.33 \mathrm{a}$ & $911 \pm 77.43 \mathrm{bcd}$ & $952 \pm 13.70$ \\
\hline IAC $97-2289$ & $12.5 \pm 1.71 \mathrm{bcd}$ & $100.0 \pm 0.00 \mathrm{a}$ & $76.7 \pm 3.33 \mathrm{a}$ & $88.3 \pm 2.70$ & $1,026 \pm 78.69 \mathrm{a}$ & $878 \pm 28.68 \mathrm{bcd}$ & $952 \pm 16.73$ \\
\hline IAC $97-2292$ & $18.3 \pm 1.67 \mathrm{ab}$ & $50.8 \pm 11.58 \mathrm{bcd}$ & $3.3 \pm 1.05 \mathrm{~cd}$ & $27.0 \pm 4.53$ & $935 \pm 77.74 \mathrm{a}$ & $915 \pm 21.50 \mathrm{abcd}$ & $925 \pm 8.41$ \\
\hline 'BR 37' & $15.0 \pm 1.83 \mathrm{abc}$ & $25.8 \pm 9.78 \mathrm{~cd}$ & $0.8 \pm 0.83 \mathrm{~d}$ & $13.3 \pm 2.06$ & $1,060 \pm 53.45 \mathrm{a}$ & $786 \pm 65.39 \mathrm{~d}$ & $923 \pm 31.02$ \\
\hline Mean & 12.3 & $49.5 \mathrm{~A}$ & $10.6 \mathrm{~B}$ & 30.0 & $1,046.9 \mathrm{~A}$ & $977.9 \mathrm{~A}$ & $1,012.2$ \\
\hline $\mathrm{s}(\mathrm{m})$ & 2.89 & 16.46 & 5.69 & 2.08 & 146.04 & 132.28 & 38.35 \\
\hline C.V. $(\%)$ & 14.36 & 35.6 & 44.0 & 6.2 & 13.9 & 13.5 & 3.8 \\
\hline
\end{tabular}

${ }^{1}$ Means followed by the same lower case letter in the column, and upper case letter in the row, do not differ by Tukey test $(P \leq 0.05)$.

Sci. Agric. (Piracicaba, Braz.), v.61, n.6, p.584-592, Nov./Dec. 2004 
mildew (Table 5), these three lines proved to be inferior than the other treatments in an evaluation of the other criteria; therefore, these characteristics should be considered unsuitable in soybean breeding programs.

Even though there was incidence of mildew in the experiment area at Tarumã during the first year, an analysis of the means did not allow germplasm discrimination with regard to this disease (Table 5). In addition to lines IAC 97-2288, IAC 97-2289, and IAC 97-2292, IAC 94133 also showed a mean rating of 1.0 , being characterized as resistant. Among the cultivars, 'IAC-18' was prominent, since plants did not exhibit symptoms, which does not agree with the classification proposed by Embrapa (2002), where this cultivar is considered highly susceptible. In absolute terms, 'Embrapa-48' was the treatment with the highest infection rating (3.7), thus confirming its highly-susceptible classification (Embrapa, 2002).

135-day maturity group. In Ribeirão Preto, the infestation by chrysomelid beetles that occurred during the $\mathrm{R}_{3} / \mathrm{R}_{4}$ stages caused defoliations that ranged from $6.7 \%$ in IAC $78-2318$ to $18.3 \%$ in 'IAC PL-1' (Table 6), thus confirming the susceptibility of this cultivar to defoliating insects (Lourenção et al., 2002). Lines IAC-2939 and IAC 94-2864 also did not differ from IAC 78-2318; their PLAR values were 8.3 and $10 \%$, respectively.
In both locations, stink bug infestations were low; populations in Ribeirão Preto fluctuated below the EIL during the entire plant cycle, as in the other two experiments (Figure 1). In Tarumã, in both years, the stink bugs exceeded the EIL while most plants were at the maturation stage (Figure 2), when these insects do not present a high damaging potential to the crop and are usually not sampled (Hoffmann-Campo et al., 2000).

The year-treatment interaction was significant for productivity in both locations, and was also significant for LRP in Ribeirão Preto. As in the 110- and 120day maturity group germplasm experiments, the leaf retention intensity expressed by the treatments was more intense during the first year, when IAC 78-2318 showed the lowest mean $(6.7 \%)$, thus confirming that this material is little sensitive to this anomaly (Lourenção et al., 1999; 2002), differing from lines IAC $94-2853$ and IAC 93-1489, with 35.8 and $34.2 \%$ LRP, respectively (Table 6).

In terms of productivity, line IAC 93-1564 obtained the greatest mean in Ribeirão Preto during the first year $\left(1,388 \mathrm{~g}^{2} \mathrm{~m}^{-1}\right)$, differing from all other treatments, except from IAC 94-2939 (1,297 $\left.\mathrm{g}^{-1} \mathrm{~m}^{-1}\right)$ (Table 6). In the following year, again these two lines were the most productive, with 1,306 and $1,285{\mathrm{~g} 8 \mathrm{~m}^{-1}}^{1}$ respectively, not

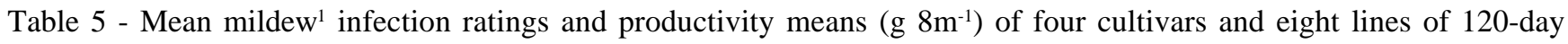
maturity group soybean, submitted to natural infestation by insects and diseases in the field. Tarumã, SP, Brazil, $1999 / 2000$ and 2000/2001 [n=6].

\begin{tabular}{|c|c|c|c|c|}
\hline \multirow{2}{*}{ Cultivar/line } & \multirow{2}{*}{$\begin{array}{c}\text { Mildew }^{2} \\
1999 / 2000\end{array}$} & \multicolumn{3}{|c|}{ Productivity $^{3}$} \\
\hline & & $1999 / 2000$ & $2000 / 2001$ & Mean \\
\hline \multicolumn{5}{|c|}{ - } \\
\hline IAC $94-1172$ & $1.8 \pm 0.17 \mathrm{a}$ & $1,082 \pm 127.39 \mathrm{ab}$ & $1,210 \pm 75.93$ a & $1,146 \pm 17.17$ \\
\hline IAC $94-5$ & $2.0 \pm 0.00 \mathrm{a}$ & $1,136 \pm 173.22 \mathrm{a}$ & $1,094 \pm 65.98 \mathrm{a}$ & $1,115 \pm 14.46$ \\
\hline IAC $94-1017$ & $2.2 \pm 0.17$ a & $1,015 \pm 154.92 \mathrm{ab}$ & $1,131 \pm 73.47 \mathrm{a}$ & $1,073 \pm 39.50$ \\
\hline 'IAC 18 ' & $1.0 \pm 0.00 \mathrm{a}$ & $957 \pm 97.98 \mathrm{ab}$ & $1,086 \pm 56.53 \mathrm{a}$ & $1,021 \pm 9.21$ \\
\hline IAC $94-745$ & $1.2 \pm 0.00 \mathrm{a}$ & $930 \pm 110.17 \mathrm{ab}$ & $1,077 \pm 105.25 \mathrm{a}$ & $1,003 \pm 28.11$ \\
\hline 'BR 37' & $2.0 \pm 0.00 \mathrm{a}$ & $794 \pm 101.78 \mathrm{ab}$ & $1,190 \pm 83.57 \mathrm{a}$ & $992 \pm 38.08$ \\
\hline 'Embrapa 48' & $3.7 \pm 0.21 \mathrm{a}$ & $729 \pm 72.07 \mathrm{ab}$ & $1,210 \pm 107.38 \mathrm{a}$ & $969 \pm 46.26$ \\
\hline IAC $94-133$ & $1.0 \pm 0.00 \mathrm{a}$ & $922 \pm 93.68 \mathrm{ab}$ & $1,006 \pm 65.46 \mathrm{ab}$ & $964 \pm 14.05$ \\
\hline IAC $97-2288$ & $1.0 \pm 0.00 \mathrm{a}$ & $1,024 \pm 98.12 a b$ & $712 \pm 44.89 \mathrm{~b}$ & $868 \pm 30.83$ \\
\hline IAC 97-2292 & $1.0 \pm 0.00 \mathrm{a}$ & $948 \pm 74.51 \mathrm{ab}$ & $711 \pm 56.63 b$ & $829 \pm 30.38$ \\
\hline 'IAC 100' & $1.5 \pm 0.22 \mathrm{a}$ & $583 \pm 28.99 b$ & $950 \pm 34.84 \mathrm{ab}$ & $766 \pm 43.31$ \\
\hline IAC $97-2289$ & $1.0 \pm 0.00 \mathrm{a}$ & $672 \pm 41.67 \mathrm{~b}$ & $341 \pm 63.43 \mathrm{~b}$ & $506 \pm 45.61$ \\
\hline Mean & 1.6 & 899.3 B & $976.5 \mathrm{~A}$ & 937.7 \\
\hline $\mathrm{s}(\mathrm{m})$ & 0.13 & 253.87 & 179.89 & 78.96 \\
\hline C.V. (\%) & 1.1 & 28.1 & 18.4 & 8.5 \\
\hline
\end{tabular}

${ }^{1}$ Rating scale ranging from 1 to 5 , where $1=$ absence of symptoms in the leaves ... $5=$ more than $50 \%$ of leaves with mildew.

${ }^{2}$ Means followed by the same letter in the column do not differ among themselves by the Kruskal-Wallis and multiple comparisons nonparametric tests $(P<0.05)$

${ }^{3}$ Means followed by the same lower case letter in the column, and upper case letter in the row, do not differ among themselves by Tukey test $(P \leq 0.05)$. 
differing only from line IAC 93-1489, with 1,105 $\mathrm{g} \mathrm{m}^{-1}$. In Tarumã, IAC 93-1564 repeated its productivity perfor-

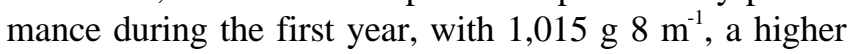
mean than that for 'IAC PL-1'; in the second year, IAC 94-2939 was outstanding, with 1,186 $\mathrm{g}^{-1}$, differing from IAC 93-1564, IAC 94-2864, IAC 78-2318, and 'IAC PL-1'. As verified in previous years (Lourenção et al.,
2002), this cultivar obtained the lowest productivity indices among all treatments in both Tarumã and Ribeirão Preto.

In Tarumã, mildew symptoms were more intense in 'IAC PL-1' and line IAC 93-1489 plants, even though their mean ratings did not differ from those of genotypes that did not show symptoms (Table 7).

Table 6 - Means for percentage leaf area removed (PLAR) by chrysomelid beetles, leaf retention percentage (LRP), and

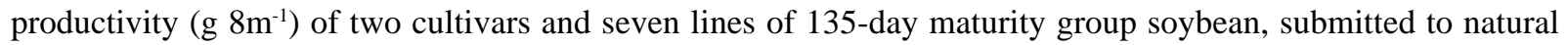
infestation by insects in the field. Ribeirão Preto, SP, Brazil, 1999/2000 and 2000/2001 [n=6].

\begin{tabular}{|c|c|c|c|c|c|c|c|}
\hline \multirow{2}{*}{ Cultivar/line } & \multirow{2}{*}{$\begin{array}{c}\text { PLAR }^{1} \\
1999 / 2000\end{array}$} & \multicolumn{3}{|c|}{$\mathrm{LRP}^{1}$} & \multicolumn{3}{|c|}{ Productivity $^{1}$} \\
\hline & & $1999 / 2000$ & $2000 / 2001$ & Mean & $1999 / 2000$ & $2000 / 2001$ & Mean \\
\hline & \multicolumn{4}{|c|}{ - } & \multicolumn{3}{|c|}{ - } \\
\hline IAC 93-1564 & $12.5 \pm 1.12 \mathrm{bc}$ & $11.7 \pm 4.01 \mathrm{ab}$ & $6.7 \pm 3.33 \mathrm{a}$ & $9.2 \pm 0.68$ & $1,388 \pm 52.13 \mathrm{a}$ & $1,306 \pm 22.96 \mathrm{a}$ & $1,347 \pm 10.82$ \\
\hline IAC $94-2939$ & $8.3 \pm 1.05 \mathrm{~cd}$ & $14.2 \pm 5.07 \mathrm{ab}$ & $10.8 \pm 2.71 \mathrm{a}$ & $12.5 \pm 0.63$ & $1,297 \pm 45.10 \mathrm{ab}$ & $1,285 \pm 41.75 \mathrm{a}$ & $1,291 \pm 5.39$ \\
\hline 'Conquista' & $12.5 \pm 1.12 \mathrm{bc}$ & $14.2 \pm 3.96 \mathrm{ab}$ & $6.7 \pm 1.05 \mathrm{a}$ & $10.4 \pm 0.50$ & $1,205 \pm 21.37 b c$ & $1,046 \pm 43.62 \mathrm{bc}$ & $1,125 \pm 18.84$ \\
\hline IAC 93-1489 & $14.2 \pm 1.54 \mathrm{ab}$ & $34.2 \pm 8.80 \mathrm{a}$ & $6.7 \pm 1.67 \mathrm{a}$ & $20.4 \pm 2.17$ & $1,002 \pm 32.16 \mathrm{~d}$ & $1,105 \pm 55.46 \mathrm{ab}$ & $1,053 \pm 13.52$ \\
\hline IAC $94-2764$ & $11.7 \pm 1.67 \mathrm{bc}$ & $28.3 \pm 6.67 \mathrm{ab}$ & $11.7 \pm 3.80 \mathrm{a}$ & $20.0 \pm 1.72$ & $1,045 \pm 37.46 \mathrm{~cd}$ & $896 \pm 69.65 \mathrm{bcd}$ & $970 \pm 21.98$ \\
\hline IAC $94-2853$ & $14.2 \pm 1.54 \mathrm{ab}$ & $35.8 \pm 11.79 \mathrm{a}$ & $14.2 \pm 2.71 \mathrm{a}$ & $25.0 \pm 2.06$ & $926 \pm 33.55 \mathrm{~d}$ & $889 \pm 45.78 \mathrm{~cd}$ & $907 \pm 12.80$ \\
\hline IAC $78-2318$ & $6.7 \pm 1.05 \mathrm{~d}$ & $6.7 \pm 2.11 b$ & $3.3 \pm 1.67 \mathrm{a}$ & $5.0 \pm 0.57$ & $894 \pm 41.38 \mathrm{de}$ & $902 \pm 34.77 \mathrm{bcd}$ & $898 \pm 2.54$ \\
\hline IAC $94-2864$ & $10.0 \pm 0.00 \mathrm{bcd}$ & $15.0 \pm 5.48 \mathrm{ab}$ & $5.0 \pm 1.83 \mathrm{a}$ & $10.0 \pm 1.25$ & $1,037 \pm 48.73 \mathrm{~cd}$ & $692 \pm 84.52 \mathrm{~d}$ & $864 \pm 34.18$ \\
\hline 'IAC PL-1' & $18.3 \pm 1.05 \mathrm{a}$ & $12.5 \pm 4.23 \mathrm{ab}$ & $15.8 \pm 4.55 \mathrm{a}$ & $14.1 \pm 0.24$ & $740 \pm 51.01 \mathrm{e}$ & $755 \pm 49.42 \mathrm{~d}$ & $747 \pm 9.98$ \\
\hline Mean & 12.0 & $19.2 \mathrm{~A}$ & $9.0 \mathrm{~B}$ & 14.1 & $1,059.3 \mathrm{~A}$ & $986.2 \mathrm{~A}$ & $1,022.4$ \\
\hline $\mathrm{s}(\mathrm{m})$ & 2.35 & 10.68 & 8.14 & 1.73 & 96.34 & 113.93 & 37.06 \\
\hline C.V. $(\%)$ & 11.74 & 44.5 & 53.5 & 7.8 & 9.1 & 11.6 & 3.6 \\
\hline
\end{tabular}

Means followed by the same lower case letter in the column or upper case letter in the row, do not differ among themselves by Tukey test $(P \leq 0.05)$.

Table 7 - Mean mildew ${ }^{1}$ infection ratings, mean percentage leaf area removed (PLAR) by chrysomelid beetles, and mean

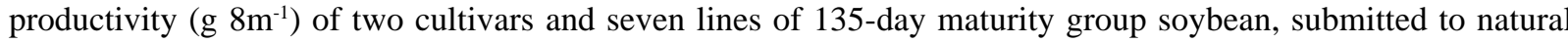
infestation by insects in the field. Tarumã, SP, Brazil, 1999/2000 and 2000/2001 [n =6].

\begin{tabular}{|c|c|c|c|c|c|}
\hline \multirow{2}{*}{ CultivaWr/line } & \multirow{2}{*}{$\frac{\text { Mildew }^{2}}{1999 / 2000}$} & \multirow{2}{*}{$\frac{\text { PLAR }^{3}}{1999 / 2000}$} & \multicolumn{3}{|c|}{ Productivity $^{3}$} \\
\hline & & & $1999 / 2000$ & $2000 / 2001$ & Mean \\
\hline & & $\%$ & -...- & g $8 m^{-1}$ & (n-..... \\
\hline IAC 94-2764 & $1.3 \pm 0.21 \mathrm{a}$ & $13.3 \pm 3.07 \mathrm{~b}$ & $943 \pm 133.55 \mathrm{ab}$ & $1,082 \pm 83.41 \mathrm{ab}$ & $1,012 \pm 21.84$ \\
\hline IAC 94-2939 & $1.0 \pm 0.00 \mathrm{a}$ & $5.8 \pm 0.83 \mathrm{bc}$ & $734 \pm 146.61 \mathrm{ab}$ & $1,186 \pm 51.08 \mathrm{a}$ & $960 \pm 42.12$ \\
\hline IAC 93-1564 & $1.0 \pm 0.00 \mathrm{a}$ & $7.5 \pm 1.71 \mathrm{bc}$ & $1,015 \pm 112.37 \mathrm{a}$ & $785 \pm 92.15 \mathrm{~cd}$ & $900 \pm 37.09$ \\
\hline IAC 94-2864 & $1.3 \pm 0.21 \mathrm{a}$ & $7.5 \pm 1.71 \mathrm{bc}$ & $853 \pm 76.43 \mathrm{ab}$ & $872 \pm 59.64 \mathrm{bcd}$ & $862 \pm 9.73$ \\
\hline IAC 94-2853 & $1.2 \pm 0.17 \mathrm{a}$ & $5.8 \pm 0.83 \mathrm{bc}$ & $618 \pm 67.07 \mathrm{ab}$ & $1,030 \pm 63.54 \mathrm{abc}$ & $824 \pm 40.37$ \\
\hline IAC 78-2318 & $1.3 \pm 0.21 \mathrm{a}$ & $3.3 \pm 1.05 \mathrm{c}$ & $904 \pm 117.59 \mathrm{ab}$ & $732 \pm 19.92 \mathrm{~d}$ & $818 \pm 16.22$ \\
\hline IAC 93-1489 & $2.0 \pm 0.00 \mathrm{a}$ & $5.8 \pm 0.83 \mathrm{bc}$ & $656 \pm 56.94 \mathrm{ab}$ & $936 \pm 46.86 \mathrm{abcd}$ & $796 \pm 36.36$ \\
\hline 'Conquista' & $1.2 \pm 0.17 \mathrm{a}$ & $5.8 \pm 0.83 \mathrm{bc}$ & $614 \pm 49.45 \mathrm{ab}$ & $974 \pm 49.65 \mathrm{abcd}$ & $794 \pm 38.24$ \\
\hline 'IAC PL-1' & $2.0 \pm 0.00 \mathrm{a}$ & $25.0 \pm 1.67 \mathrm{a}$ & $523 \pm 54.29 \mathrm{~b}$ & $253 \pm 76.09 \mathrm{e}$ & $388 \pm 31.71$ \\
\hline Mean & 1.4 & 8.9 & $762.2 \mathrm{~B}$ & $872.2 \mathrm{~A}$ & 817.1 \\
\hline $\mathrm{s}(\mathrm{m})$ & 0.17 & 4.16 & 241.76 & 148.12 & 78.67 \\
\hline C.V. $(\%)$ & 1.5 & 25.7 & 31.7 & 17.0 & 9.4 \\
\hline
\end{tabular}

${ }^{1}$ Rating scale ranging from 1 to 5 , where $1=$ absence of symptoms in the leaves $\ldots 5=$ more than $50 \%$ of leaves with mildew.

${ }^{2}$ Means followed by the same letter in the column do not differ among themselves by the Kruskal-Wallis and multiple comparisons nonparametric tests $(P<0.05)$.

${ }^{3}$ Means followed by the same lower case letter in the column, and upper case letter in the row, do not differ by Tukey test $(P \leq 0.05)$.

Sci. Agric. (Piracicaba, Braz.), v.61, n.6, p.584-592, Nov./Dec. 2004 
The occurrence of leaf retention in soybean has been associated with the attack of stink bugs (Daugherty et al., 1964) and species involved, drought during flowering and/or during the pod development period, excess moisture in the maturation period (Sosa-Gomez \& Moscardi, 1995), absence of pods in the plant (Hicks \& Pendleton, 1969), and potassium deficiencies or high (Ca $+\mathrm{Mg}) / \mathrm{K}$ ratio values (Mascarenhas et al., 1987; 1988). Since fertilizations were carried out according to the crop's requirements in the experimental areas of both locations based on soil analyses, and because infestations by stink bugs oscillated below the EIL, it is likely that the high LRP values observed were influenced by climate-related factors, during critical plant development periods. Regardless of the cause, it was possible to discriminate germplasm that was less sensitive to this physiological disorder.

Considering both localities and both cropping seasons, it can be seen that for 110-day maturity group germplasm, line IAC 94-2675 presents good productivity, low leaf retention, and high resistance to mildew. In the 120-day maturity group, lines IAC 94-5, IAC 941172, IAC 94-1017, IAC 94-133, and IAC 94-745 show good productivity levels, and similar leaf retention and defoliation indices; the latter two lines are also resistant to mildew. Among the 135-day maturity group genotypes, lines IAC 93-1564 and IAC 94-2939 stand out as resistant to mildew, with low leaf retention indices and good productivity, and thus deserve to be evaluated in new regional assays.

\section{ACKNOWLEDGEMENTS}

To Conselho Nacional de Desenvolvimento Científico e Tecnológico $(\mathrm{CNPq})$, for granting a productivity research scholarship to the first author and to $\mathrm{Mr}$. Sílvio Roberto Nascimento for technical support in the field.

\section{REFERENCES}

ADKISSON, P.L.; DYCK, V.A. Resistant varieties in pest management systems. In: MAXWELL, F.G.; JENNINGS, P.R. (Ed.) Breeding plants resistant to insects. New York: John Wiley \& Sons, 1980. cap.11, p.233251.

DAUGHERTY, D.M.; NEUSTADT, M.H.; GEHRKE, C.W.; CAVANAH, L.E.; WILLIAMS, L.F.; GREEN, D.E. An evaluation of damage to soybeans by brown and green stink bugs. Journal of Economic Entomology, v.57, p.719-722, 1964.

EMPRESA BRASILEIRA DE PESQUISA AGROPECUÁRIA. Tecnologias de produção de soja - Região Central do Brasil - 2003. Londrina: Embrapa Soja, 2002. 199p. (Sistemas de Produção, 1).

FEHR, W.R.; CAVINESS, C.E. Stages of soybean development. Ames: Iowa State University, Cooperative Extension Service, 1977. 12p. (Special Report, 80).

FNP CONSULTORIA E COMÉRCIO. Agrianual. Anuário da Agricultura Brasileira. São Paulo, 2003. 544p.
HICKS, D.R.; PENDLETON, J.W. Effect of floral bud removal on performance of soybean. Crop Science, v.9, p.435-437, 1969.

HOFFMANN-CAMPO, C.B.; MOSCARDI, F.; CORRÊA-FERREIRA, B.S.; OLIVEIRA, L.J.; SOSA-GOMEZ, D.R.; PANIZZI, A.R.; CORSO, I.C.; GAZZONI, D.L.; OLIVEIRA, E.B. Pragas da soja no Brasil e seu manejo integrado. Londrina: Embrapa Soja, 2000. 70p. (Circular Técnica, 30).

JENSEN, R.L.; NEWSOM, L.D. Effect of stink-bug-damaged soybean seeds on germination, emergence and yield. Journal of Economic Entomology, v.65, p.261-264, 1972.

LOURENÇÃO, A.L.; MIRANDA, M.A.C. Resistência de soja a insetos: VIII. IAC 78-2318, linhagem com resistência múltipla. Bragantia, v.46, p.65-72, 1987.

LOURENÇÃO, A.L.; PEREIRA, J.C.V.N.A.; MIRANDA, M.A.C.; AMBROSANO, G.M.B. Danos de percevejos e de lagartas em cultivares e linhagens de soja de ciclos médio e semi-tardio. Anais da Sociedade Entomológica do Brasil, v.28, p.157-167, 1999.

LOURENÇÃO, A.L.; BRAGA, N.R.; MIRANDA, M.A.C.; VALLE, G.E.; PEREIRA, J.C.V.N.A.; RECO, P.C. Avaliação de danos de percevejos e de desfolhadores em genótipos de soja de ciclos precoce, semiprecoce e médio. Neotropical Entomology, v.31, p.623-630, 2002.

MASCARENHAS, H.A.A.; MIRANDA, M.A.C.; LELIS, L.G.L.; BULISANI, E.A.; BRAGA, N.R.; PEREIRA, J.C.V.N.A. Haste verde e retenção foliar em soja causada por deficiência de potássio. Campinas: Instituto Agronômico, 1987. 16p. (Boletim Técnico, 119).

MASCARENHAS, H.A.A.; MIRANDA, M.A.C.; NOGUEIRA, S.S.S.; BULISANI, E.A. Senescência anormal em soja decorrente de distúrbios fisiológicos. O Agronômico, v.40, p.130-138, 1988.

MIRANDA, M.A.C.; LOURENÇÃO, A.L. Melhoramento genético da soja para resistência a insetos: uma realidade para aumentar a eficiência do controle integrado de pragas e viabilizar a soja orgânica. In: CONGRESSO BRASILEIRO DE SOJA E MERCO-SOJA, 2., Foz do Iguaçu, 2002. Anais. Londrina: Embrapa Soja, 2002. p.52-60.

MIRANDA, M.A.C.; BRAGA, N.R.; LOURENÇÃO, A.L.; MIRANDA, F.T.S.; UNÊDA, S.H.; ITO, M.F. Descrição, produtividade e estabilidade da cultivar de soja IAC-23, resistente a insetos. Bragantia, v.62, p.1927, 2003a

MIRANDA, M.A.C.; BRAGA, N.R.; LOURENÇÃO, A.L.; MIRANDA, F.T.S.; UNÊDA, S.H.; ITO, M.F. Descrição, produtividade e estabilidade da cultivar de soja IAC-24, resistente a insetos. Bragantia, v.62, p.29$37,2003 \mathrm{~b}$

RAIJ, B. van; CANTARELLA, H.; QUAGGIO, J.A.; FURLANI, A.M.C. Recomendações de adubação e calagem para o estado de São Paulo. Campinas: Instituto Agronômico, Fundação IAC, 1997. 285p. (Boletim Técnico, 100).

REZENDE, J.A.M.; MIRANDA, M.A.C.; MASCARENHAS, H.A.A. Comportamento de cultivares de soja em relação à área foliar comida por lagartas das folhas. Bragantia, v.39, p.161-165, 1980.

ROSSETTO, C.J. Breeding for resistance to stink bugs. In: CONFERENCIA MUNDIAL DE INVESTIGACIÓN EM SOJA, 4., Buenos Aires, 1989. Actas. Buenos Aires: Orientación Gráfica Editora SRL, 1989. v.4, p.2046-2060.

SOSA-GÓMEZ, D.R.; MOSCARDI, F. Retenção foliar diferencial em soja provocada por percevejos (Heteroptera : Pentatomidae). Anais da Sociedade Entomológica do Brasil, v.24, p.401-404, 1995.

VALLE, G.E.; LOURENÇÃO, A.L. Resistência de genótipos de soja a Bemisia tabaci(Genn.) biótipo B (Hemiptera: Aleyrodidae). Neotropical Entomology, v.31, p.285-295, 2002.

YORINORI, J.T. Doenças da soja no Brasil. In: FUNDAÇÃO CARGILL. A soja no Brasil central. Campinas: Fundação Cargill, 1982. cap.8, p.301-364.

Received July 17, 2003

Accepted September 29, 2004 